\title{
PENGEMBANGAN MEDIA WEBSITE HYBRID LEARNING BERBASIS KEMAMPUAN LITERASI DIGITAL DALAM PEMBELAJARAN FISIKA
}

\author{
Tetra Rahayu \\ Tantri Mayasari \\ Farida Huriawati \\ Progam Studi Pendidikan Fisika, Universitas PGRI Madiun \\ Email: tetrarahayu61@gmail.com
}

\begin{abstract}
This research was conducted to: (1) develop Hybrid learning website media based on digital literacy skills in physics learning, (2) describe the characteristics of products developed, (3) describe students' responses to the developed media. The device developed in the form of Hybrid learning website media based on digital literacy skills in physics learning with the development procedure used is the ADDIE model which consists of five stages: analysis, design, development, implementation and evaluation. Media characteristics of Hybrid learning websites based on digital literacy capability, namely the website media developed has been based on the concept of Hybrid learning and integrated with the dimensions of digital literacy capabilities. Student responses to Hybrid learning website media based on digital literacy ability are still in good condition with a percentage of $79.85 \%$.
\end{abstract}

Keywords: Hybrid learning, digital literacy.

\section{PENDAHULUAN}

Menghadapi perkembangan pesat era globalisasi pada abad ke 21, guru dan institusi pendidikan diminta untuk menyiapkan siswa mereka agar memiliki kompetensi atau keterampilan. Konsep keterampilan abad 21 menurut tim Raizen berfokus pada empat kategori, yaitu ways of thinking atau cara berpikir (kreativitas, pemikiran kritis, pemecahan masalah, pengambilan keputusan, pembelajaran dan inovasi), ways of working atau cara bekerja (komunikasi dan kolaborasi), tools for working atau alat bekerja (TIK dan literasi informasi /literasi digital), living in the world atau kehidupan di dunia (kewarganegaraan, kehidupan dan karir, tanggung 
T, Rahayu., T, Mayasari., F, Huriawati. - Pengembangan Media Website ...

jawab pribadi dan sosial) (Griffin \& Care, 2015). Sebagai konsekuensinya, guru harus merancang kegiatan pembelajaran yang dapat memenuhi tuntutan kompetensi mereka. Salah satu caranya adalah melalui integrasi ICT (information, communication, and technology) dengan proses pembelajaran untuk melatih siswa tentang literasi informasi dan literasi TIK. Kenyataannya, pengintegrasikan ICT dalam mata pelajaran fisika di SMK Gamaliel 1 Madiun masih sangat rendah dalam beberapa dimensi atau aspek, yaitu aspek teknis mengenai keterampilan siswa dalam membuat situs web menggunakan HTML dasar untuk keperluan pembelajaran fisika hanya mencapai 46,7\% dari 15 siswa untuk kelas $X$ TAV dan 34,8\% dari 23 siswa kelas $\mathrm{X}$ TPM C.

Aspek teknis lain, yaitu keterampilan ICT/TIK (keterampilan umum mengenai hardware, software dan server) yang masih rendah sebesar 46,7\% dari 15 siswa pada kelas X TAV dan 43,5\% dari 23 siswa kelas X TPM C. Selain itu, kemampuan pada aspek kognitif mengenai pengetahuan siswa tentang masalah yang berkaitan dengan web berbasis kegiatan atau organisasi misalnya keamanan cyber (mengatasi kejahatan di internet), kesulitan dalam mencari sumber informasi yang akurat, serta plagiarisme hanya sebesar 46,7\% dari 15 siswa pada kelas TAV dan 43,5\% dari 23 siswa untuk kelas X TPM C, (Rahayu \& Mayasari, 2018). TIK terutama internet hanya digunakan sebagai sumber untuk mencari materi pembelajaran dan pertanyaan. Selain itu, hasil observasi yang dilakukan di SMK Gamaliel 1 Madiun bahwa media pembelajaran yang selama ini digunakan dalam pembelajaran fisika berupa kategori media cetak (buku paket fisika SMK kurikulum 2013), kategori media visual (chart, gambar, foto, slide, microsoft powerpoint), kategori media audio visual (video, slide microsoft powerpoint dengan speaker). Pada beberapa kategori media pembelajaran yang telah digunakan, belum tersedianya media pembelajaran yang terintegrasi literasi digital.

Di sisi lain, guru sering merasakan waktu yang terbatas untuk melakukan pembelajaran secara tatap 
muka. Pembelajaran ini mencakup topik-topik lanjutan. Karena waktu terbatas, sebagian besar tugas diberikan kepada siswa biasanya tanpa umpan balik. Sementara itu, pengguna internet kelompok usia remaja (usia sekolah) kian besar. Kelompok usia 13-18 tahun mencapai $75,50 \%$ dari total pengguna internet.

Survei membuktikan, perangkat yang sering digunakan untuk mengakses internet, yaitu smartphone/tablet digunakan oleh $44,16 \%$ pengguna, komputer/laptop $4,49 \%$ pengguna sedangkan gabungan antara smartphone/tablet dan komputer/laptop mencapai 44,16\% dari total pengguna internet 143,26 juta jiwa (APJII, 2017). Di sekolah SMK Gamaliel 1 Madiun, akses wifi tidak terbatas sehingga siswa dapat menggunakan secara maksimal. Para siswa yang tidak memiliki koneksi internet di rumah, mereka menyatakan dapat mengaksesnya melalui koneksi internet mobile phone atau android. Namun, masih banyak siswa menyatakan bahwa kecepatannya koneksi internet tidak cukup cepat. Survei menunjukkan bahwa akses pengguna akan internet mendukung untuk mengintegrasikan internet di Indonesia dalam proses pembelajaran.

$$
\text { Salah satu bentuk }
$$
pengintegrasian internet dalam proses belajar adalah dengan penerapan Hybrid learning. Menerapkan Hybrid learning dalam pembelajaran fisika dengan menggunakan media pembelajaran berbasis website dapat meningkatkan kemampuan literasi ICT (literasi digital) siswa. Hal ini dikuatkan oleh penelitian Husamah (2014) ciri teknologi internet yang selalu dapat diakses kapan saja, di mana saja, multiuser serta menawarkan segala kemudahannya telah menjadikan internet suatu media yang sangat tepat bagi perkembangan pendidikan jarak jauh selanjutnya. Hal ini lah mengapa untuk saat ini sistem pembelajaran secara blended learning (Hybrid learning) masih sangat baik di terapkan di Indonesia agar lebih dapat terkontrol secara tradisional juga.

\section{METODE}

Penelitian Penelitian dilakukan dari Maret hingga Mei 2018 di Kelas $X$ TAV dan $X$ TPm D, SMK 
T, Rahayu., T, Mayasari., F, Huriawati. - Pengembangan Media Website ...

Gamaliel 1 Madiun. Penelitian ini menggunakan model pengembangan ADDIE (Analisis, Desain, Pengembangan, Implementasi dan Evaluasi) alur pengembangan dapat dilihat pada Gambar 1. Pemilihan prosedur pengembangan ADDIE dikarenakan merupakan model yang sering digunakan banyak peneliti untuk mengembangkan sebuah media yang berbasis multimedia seperti computer based training, web based training, distance broadcast training (Lee \& Owens, 2004) sehingga diterapkan peneliti untuk mengembangkan media website Hybrid learning berbasis kemampuan literasi digital dalam pembelajaran fisika. Pada tahapan analysis (analisis) dilakukan untuk menganalisis masalah sesuai kebutuhan siswa. Pada tahapan design (perancangan) bertujuan untuk merancang media website Hybrid learning sesuai dengan kebutuhan siswa. Selanjutnya, pada tahap development (pengembangan) dilakukan pembuatan produk media dari rancangan yang telah ada.
Selain itu, dilakukan pengujian kelayan produk melalui validasi ahli dan validasi empiris. Tahap implementasi bertujuan untuk menerapkan media pembelajaran di sekolah. Evaluasi dilakukan untuk mengetahui kelebihan dan kekurangan pengembangan produk. Instrumen yang digunakan pada penelitian ini berupa angket, lembar observasi dan tes soal kemampuan literasi digital yang mengacu pada 4 dimensi literasi digital, yaitu sosialemosional (indikator: kerja tim, jaringan, berbagi, etika, literasi legal, menjaga diri); sikap (indikator: ketertarikan, kepercayaan diri, keingintauan, keterbukaan terhadap pengalaman); teknis (kognisi, penemuan, presentasi); kognitif (analisis, evaluasi, kreativitas). Analisis data yang dilakukan berupa analisis kualitatif, yaitu dengan merubah data berbentuk angkaangka menjadi deskripsi pengkategorian kriteria interprestasi. Teknik untuk menganalisis validasi ahli menggunakan persamaan dari (Lawshe, 1975). 
T, Rahayu., T, Mayasari., F, Huriawati. - Pengembangan Media Website ...

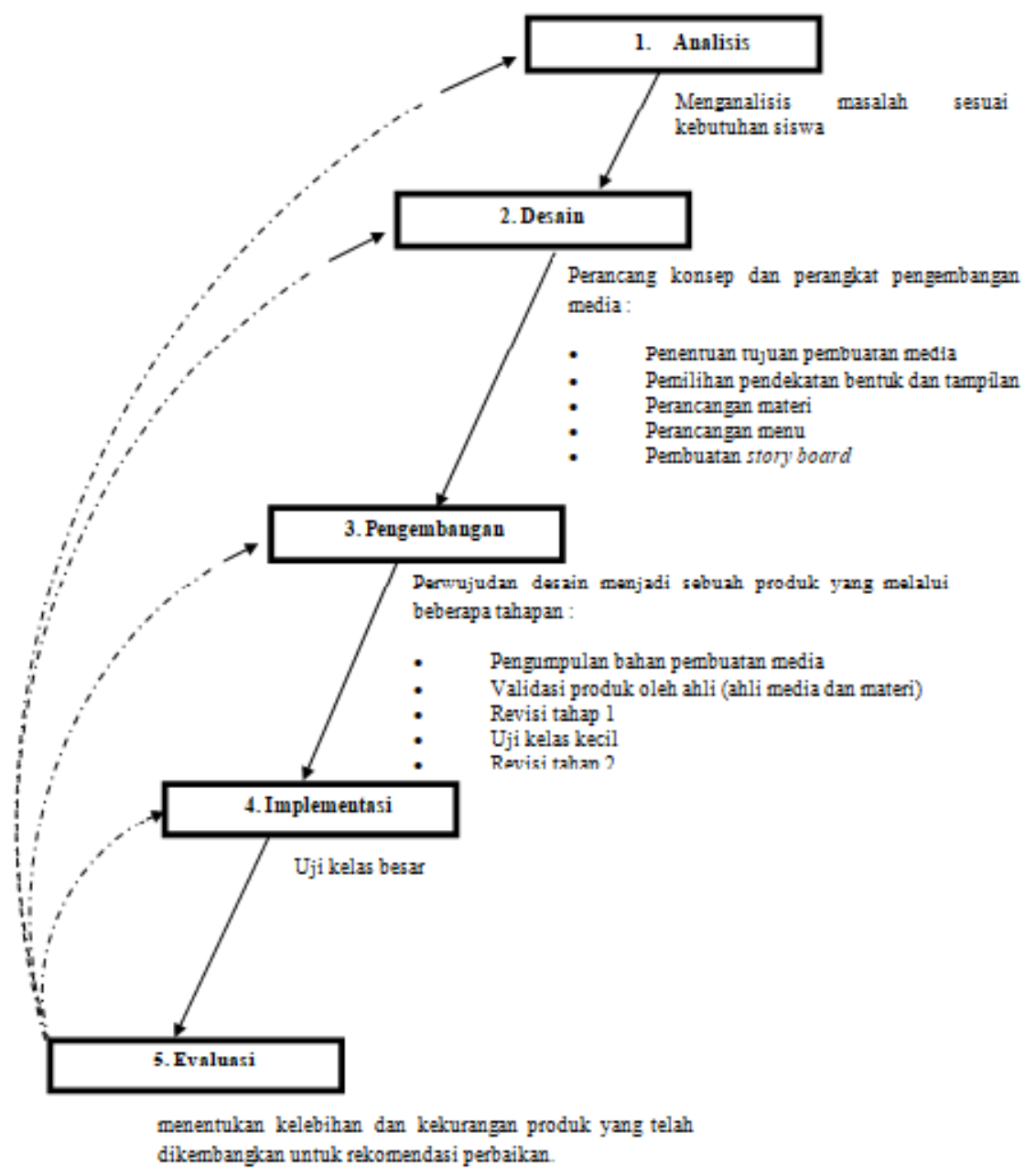

Gambar 1. Prosedur Pengembangan Website Hybrid learning berbasis Kemampuan Literasi Digital dalam Pembelajaran Fisika

\section{HASIL DAN PEMBAHASAN}

Produk yang dikembangkan pada penelitian ini berupa media website Hybrid learning berbasis kemampuan literasi digital dalam pembelajaran fisika.

\section{Analisis}

Pada pengembangan in dilakukan analisis terhadap kemampuan literasi digital dan kondisi lingkungan pembelajaran dalam penerapan Hybrid learning. Hasil dari analisis yang telah dilakukan meliputi : (1) Menurut data hasil studi pendahuluan menunjukkan bahwa kemampuan literasi digital dalam pembelajaran fisika siswa SMK Gamaliel 1 Madiun rendah dalam beberapa dimensi atau aspek. Khususnya pada aspek teknis 
mengenai keterampilan siswa dalam membuat situs web menggunakan HTML dasar untuk keperluan pembelajaran fisika hanya mencapai $46,7 \%$ dari 15 siswa untuk kelas $X$ TAV dan 34,8\% dari 23 siswa kelas $\mathrm{X}$ TPM C. Aspek teknis lain, yaitu keterampilan ICT/TIK (keterampilan umum mengenai hardware, software dan server) yang masih rendah sebesar 46,7\% dari 15 siswa pada kelas X TAV dan 43,5\% dari 23 siswa kelas X TPM C. Selain itu, kemampuan pada aspek kognitif mengenai pengetahuan siswa tentang masalah yang berkaitan dengan web berbasis kegiatan atau organisasi misalnya keamanan cyber (mengatasi kejahatan di internet), kesulitan dalam mencari sumber informasi yang akurat, serta plagiarisme hanya sebesar 46,7\% dari 15 siswa pada kelas TAV dan 43,5\% dari 23 siswa untuk kelas X TPM C (Rahayu \& Mayasari, 2018).

Berdasarkan observasi di SMK Gamaliel 1 Madiun, pembelajaran selama ini hanya dilakukan melalui materi yang disampaikan guru dengan sarana media cetak (buku paket fisika SMK kurikulum 2013), media visual (chart, gambar, foto, slide, microsoft powerpoint), media audio visual (video, slide microsoft powerpoint dengan speaker). Pada beberapa kategori media pembelajaran yang telah digunakan, belum tersedianya media pembelajaran yang terintegrasi kemampuan literasi digital. Berdasarkan masalah tersebut, diperlukan pengembangan media pembelajaran yang mampu meningkatkan kemampuan literasi digital dalam pembelajaran fisika. Pentingnya pengembangan media ini juga sejalan dengan adanya salah satu jurusan di SMK Gamaliel 1 Madiun yang memerlukan kemampuan literasi digital dalam pembelajarannya, yaitu jurusan teknik audio video (TAV). Dalam rangka menyiapkan keterampilan literasi digital, pendidikan hari ini perlu beralih dari metode pengajaran dan pembelajaran tradisional berdasarkan bahan cetak ke format digital.

Selain itu, dengan meningkatkan jumlah sumber belajar di situs web (internet) yang menyediakan berbagai macam sarana dan kesempatan belajar (Techataweewan \& Prasertsin, 2017). Hal inilah yang mendasari peneliti 
T, Rahayu., T, Mayasari., F, Huriawati. - Pengembangan Media Website ...

mengembangkan media pembelajaran berbasis website. (2) Analisis juga dilakukan dengan meninjau kondisi lingkungan pembelajaran terutama pada sarana belajar yang telah diterapkan di sekolah SMK Gamaliel 1 Madiun sehingga mampu diintegrasikan dengan media yang dikembangkan. SMK Gamaliel 1 Madiun telah memiliki fasilitas laboratorium komputer yang sangat memadai. Jumlah laboratorium komputer sekitar 4 ruang.

Pada setiap ruang mampu menampung 20 siswa. Selain itu disetiap kelas telah terpasang LCD proyektor (OHP). Jaringan wifi untuk akses siswa disediakan secara tidak terbatas sehingga siswa dapat menggunakan secara maksimal. Setiap siswa juga diperbolehkan membawa dan menerapkan laptop serta mobile phone untuk pembelajaran. Para siswa yang tidak memiliki koneksi internet di rumah, mereka menyatakan dapat mengaksesnya melalui koneksi internet mobile phone atau android.

Namun, masih banyak siswa menyatakan bahwa kecepatannya koneksi internet tidak cukup cepat.
Survei menunjukkan bahwa akses pengguna akan internet mendukung untuk mengintegrasikan internet di Indonesia dalam proses pembelajaran. Salah satu bentuk pengintegrasian internet dalam proses belajar adalah dengan penerapan Hybrid learning. Di sisi lain, guru sering merasakan waktu yang terbatas untuk melakukan pembelajaran secara tatap muka. Pembelajaran ini mencakup topiktopik lanjutan.

Karena waktu terbatas, sebagian besar tugas diberikan kepada siswa biasanya tanpa umpan balik. Berdasarkan keterangan guru fisika dan siswa SMK Gamaliel 1 Madiun, saat ini dalam mengirimkan materi dan tugas untuk siswa masih menggunakan mobile phone sehingga butuh dukungan media pembelajaran lain yang mampu digunakan sebagai sarana publikasi materi fisika untuk belajar dan tugas siswa selama di luar jam pembelajaran. Hal ini yang mendukung pengembangan media hybrid learning berbasis website yang dapat digunakan sebagai media saat pembelajaran tatap muka (face to face) maupun secara online. Hybrid learning adalah gabungan 
T, Rahayu., T, Mayasari., F, Huriawati. - Pengembangan Media Website ...

pembelajaran dalam kelas dan learning), yaitu gabungan pembelajaran secara online tanpa pembelajaran dalam kelas dan menghilangkan pembelajaran secara pembelajaran secara online tanpa tatap muka langsung (Asyrofi \& Junaedi, 2016). Semler menegaskan menghilangkan pembelajaran secara tatap muka/langsung. Proses bahwa: "Blended learning pembelajaran secara tatap muka yang mengkombinasikan aspek terbaik dari pembelajaran online, aktivitas tatap muka terstruktur, dan praktek dunia nyata (Husamah, 2014).

\section{Desain}

Desain media website Hybrid learning dirancang untuk mengatasi permalahan rendahnya kemampuan literasi digital dan keterbatasan waktu dalam pembelajaran secara tatap muka. Pada website hybrid learning terdapat beberapa menu yaitu dashboard, ruang belajar, ruang tugas, ruang diskusi, kotak masuk dan data siswa.

\section{Development}

Tujuan penelitian ini mengembangkan media website hybrid learning berbasis kemampuan literasi digital dalam pembelajaran fisika. Karakteristik produk yang dikembangkan, yaitu pengembangan media berupa website ini berlandaskan pada konsep pembelajaran hybrid (Hybrid dilakukan di kelas maupun di luar jam pembelajaran (luar kelas) yang terhambat keterbatasan waktu, jarak dapat dilakukan secara online menggunakan media website Hybrid learning berbasis kemampuan literasi digital dalam pembelajaran fisika yang dikembangkan. Media website Hybrid learning ini sangat layak digunakan karena memiliki kelebihan, yaitu Hybrid learning dapat diakses kapan saja (tidak terbatas waktu, bersifat kontinyu), di mana saja (tidak terbatas tempat), multiuser (dapat digunakan oleh banyak orang) sehingga diharapkan pembelajaran dapat dilakukan secara intensif karena interaksi guru dan siswa dapat dilakukan secara berkelanjutan. Media yang digunakan pada Hybrid learning ini berupa website yang dibangun melalui prinsip interaksi, ketergunaan dan relevansi yang berperan dalam menentukan keberhasilan proses pembelajaran. 
T, Rahayu., T, Mayasari., F, Huriawati. - Pengembangan Media Website ...

Media website Hybrid learning berbasis kemampuan literasi digital ini telah berlandaskan konsep media Hybrid learning karena dapat digunakan dalam pembelajaran tatap muka maupun online dan mendukung penyampaian pembelajaran jarak jauh. Produk media ini mampu meningkatkan kemampuan literasi digital karena pada proses pengembangan telah berlandaskan dimensi literasi digital, yaitu sosialemosional (indikator : kerja tim, jaringan, berbagi, etika, literasi legal, menjaga diri); sikap (indikator : ketertarikan, kepercayaan diri, keingintauan, keterbukaan terhadap pengalaman); teknis (indikator : kognisi, penemuan, presentasi); kognitif (indikator : analisis, evaluasi, kreativitas). Media website Hybrid learning berbasis kemampuan literasi digital memiliki spesifikasi menu yang mengandung konten terintegrasi dengan dimensi literasi digital. Pada tahap pengembangan ini dilakukan beberapa kegiatan meliputi :

1) Pembuatan website dari rancangan storyboard menumenu pada media website Hybrid learning yang telah ada. tampilan menu dan fungsi dari masingmasing menu dapat dilihat pada gambar 2.

Berikut merupakan fungsi dari beberapa menu yang ada: (a). Halaman utama (dashboard) : tampilan awal media setelah pengguna (user) berhasil masuk ke dalam program. (b). Ruang belajar yang terintegrasi dengan dimensi kognitif dan dimensi sikap : berisi materi fisika yang dapat menunjang pembelajaran fisika di dalam kelas secara tatap muka maupun di luar jam sekolah secara tidak tatap muka, serta ruang materi literasi untuk melatihkan kemampuan literasi digital siswa pada dimensi kognitif dan dimensi sikap. (c). Ruang diskusi terintegrasi dengan dimensi sosial-emosional dan dimensi sikap : ruang diskusi antara guru dan siswa terkait pembelajaran jika ada kesulitan dalam belajar yang bisa di lakukan tanpa tatap muka dan berfungsi untuk melatihkan kemampuan literasi digital pada dimensi sosial-emosional dan dimensi sikap. (d). Ruang tugas 
T, Rahayu., T, Mayasari., F, Huriawati. - Pengembangan Media Website ...

terintegrasi dengan dimensi

teknis dan dimensi sikap : berisi

tugas terkait materi fisika

maupun literasi yang dikemas

secara online diberikan oleh guru

di saat pembelajaran tatap muka

maupun di luar pembelajaran

sekolah dan dapat didownload

oleh siswa serta upload jawaban kembali. (e). Kotak masuk : menu ini diperuntukkan untuk admin (guru) sebagai tempat masuk tugas yang telah dikirim oleh siswa. (f).Data siswa: menu ini hanya terdapat pada admin media (guru) yang berfungsi untuk menampilkan identitas siswa pengguna media.

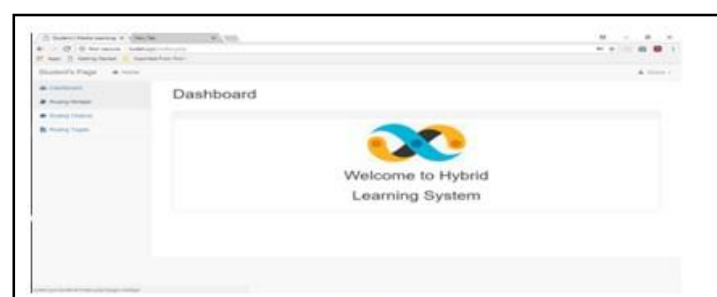

(a)

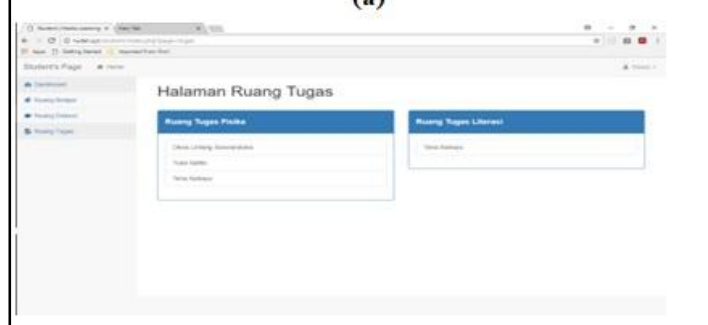

(b)

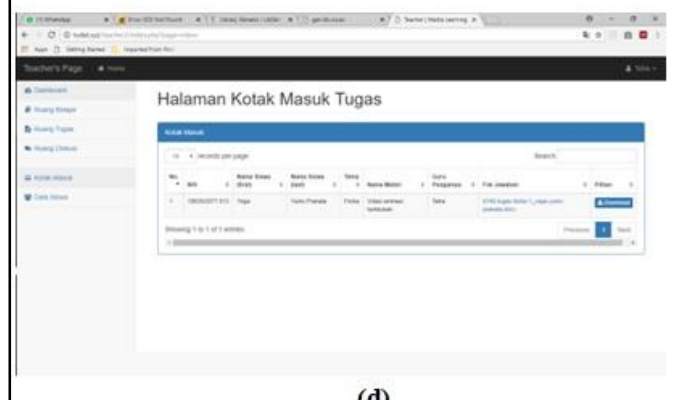

(d)

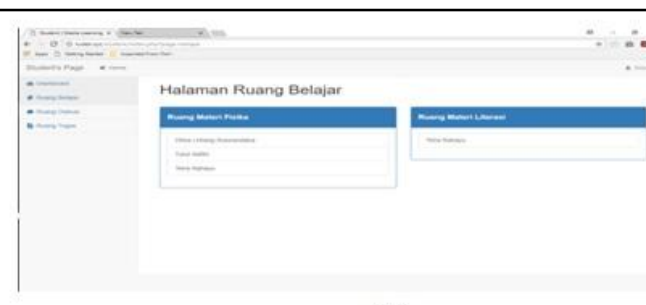

(b)

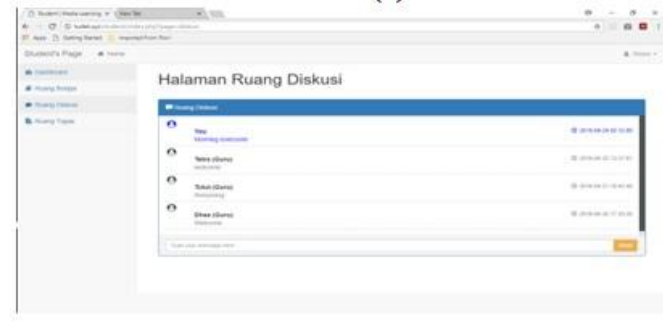

(c)

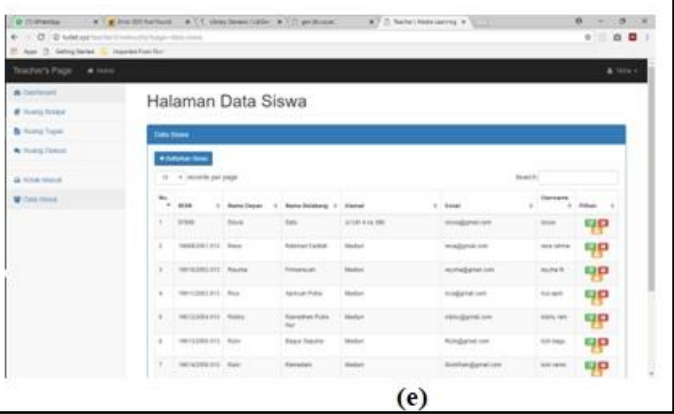

(e)

Gambar 2. Tampilan-Tampilan Menu Media Website Hybrid Learning Berbasis Kemampuan Literasi Digital

2) Validasi ahli media dilakukan oleh 5 pakar ahli media terhadap media yang dikembangkan sehingga didapatkan hasil content validity ratio (CVR) dan content validity index (CVI) sebesar 1. 
T, Rahayu., T, Mayasari., F, Huriawati. - Pengembangan Media Website ...

3) Revisi tahap 1 dilakukan dengan memperbaiki media berdasarkan saran yang diberikan oleh ahli.

4) Uji coba kelas kecil (validasi empiris) dilakukan pada media Hybrid learning berbasis website untuk mengetahui kelayakan produk berdasarkan respon siswa terhadap media. Hasilnya, media termasuk pada kriteria baik dengan presentase $79,88 \%$.
5) Revisi tahap 2, dilakukan perbaikan pada pengoptimalan jaringan internet ketika menyambungkan ke situs media dikarenakan pada tahap uji kelas kecil telah dinyatakan layak digunakan oleh validator empiris (siswa kelas X TAV) dan kendala yang ditemui hanya pada hambatan akses internet.

Tabel 1. Saran Perbaikan Media Website Hybrid Learning

\begin{tabular}{|c|c|c|c|}
\hline $\begin{array}{c}\text { Aspek } \\
\text { Pengujian }\end{array}$ & Indikator & Saran Perbaikan & Perbaikan \\
\hline Usability & $\begin{array}{c}\text { Efisiensi } \\
\text { penggunaan } \\
\text { Website }\end{array}$ & $\begin{array}{c}\text { Saat didemokan } \\
\text { menggunakan versi } \\
\text { offline supaya tidak } \\
\text { terganggu jaringan } \\
\text { internet apabila } \\
\text { kondisi down }\end{array}$ & $\begin{array}{c}\text { Jaringan offline saat } \\
\text { didemokan }\end{array}$ \\
\hline Functionality & $\begin{array}{l}\text { Penggunaan } \\
\text { menu upload } \\
\text { dan download }\end{array}$ & $\begin{array}{l}\text { Saat didemokan } \\
\text { menggunakan versi } \\
\text { offline mohon } \\
\text { diperhatikan kualitas } \\
\text { jaringan internet }\end{array}$ & $\begin{array}{c}\text { Jaringan offline saat } \\
\text { didemokan }\end{array}$ \\
\hline - & - & 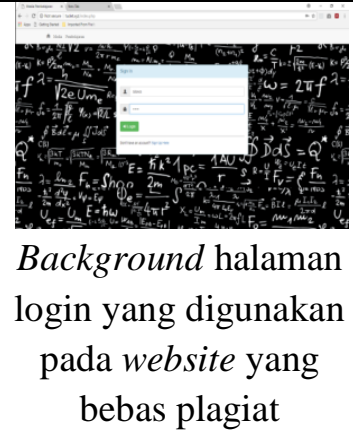 & $=$ \\
\hline
\end{tabular}


T, Rahayu., T, Mayasari., F, Huriawati. - Pengembangan Media Website ...

\section{Implementation}

Media website Hybrid learning yang dikembangkan kemudian diimplementasikan kepada 26 siswa kelas X TPm D SMK Gamaliel 1 Kota Madiun dengan presentase respon siswa terhadap media sebesar $79,85 \%$ yang masuk pada kategori baik. Hal ini menunjukkan bahwa media layak untuk digunakan pada kegiatan pembelajaran.

\section{Evaluation}

Evaluasi dilakukan untuk mengetahui kelebihan dan kekurangan dalam pengembangan media website Hybrid learning berbasis kemampuan literasi digital ini. Media ini memiliki kelebihan, yaitu (1) Pengembangan media berupa website ini telah berlandaskan pada konsep pembelajaran hybrid (Hybrid learning) sehingga proses pembelajaran secara tatap muka yang dilakukan di kelas maupun di luar jam pembelajaran (luar kelas) yang terhambat keterbatasan waktu, jarak dapat dilakukan secara online dengan penerapan media ini, (2) Media website Hybrid learning ini dapat diakses kapan saja (tidak terbatas waktu, bersifat kontinyu), di mana saja (tidak terbatas tempat), multiuser (dapat digunakan oleh banyak orang) sehingga diharapkan pembelajaran dapat dilakukan secara intensif karena interaksi guru dan siswa dapat dilakukan secara berkelanjutan dan mendukung pembelajaran jarak jauh, (3) Produk media ini mampu meningkatkan kemampuan literasi digital karena pada proses pengembangan telah berlandaskan dimensi literasi digital dengan memiliki spesifikasi menu yang mengandung konten terintegrasi dengan dimensi literasi digita, (4) Media website Hybrid learning berbasis kemampuan literasi digital ini dapat digunakan secara offline sehingga mampu mengatasi keterbatasan jaringan internet, (5) Terdapat pengaturan tombol on atau off pada tugas maupun materi yang telah diunggah sehingga mampu mengatasi kecurangan dan keterlambatan siswa pada pengumpulan tugas yang memiliki durasi pengumpulan yang ditentukan. Kelemahannya terletak pada beberapa menu dalam media yang belum mampu berfungsi secara maksimal 
T, Rahayu., T, Mayasari., F, Huriawati. - Pengembangan Media Website ...

sehingga perlu pengembangan

lanjutan.

\section{PENUTUP}

\section{Kesimpulan}

Pengembangan media website Hybrid learning berbasis kemampuan literasi digital ini merupakan media yang berlandaskan konsep pembelajaran hybrid dan telah terintegrasi dengan kemampuan literasi digital. Hasil penelitian menunjukkan bahwa media website Hybrid learning berbasis kemampuan literasi digital ini "sangat layak" untuk digunakan berdasarkan pengujian kelayakan produk berupa validasi ahli media diperoleh hasil content validity index (CVI) sebesar 1 dan hasil respon siswa terhadap media 79,85\% pada kategori "baik".

\section{Saran}

$\begin{array}{ccr}\text { Peneliti lain } & \text { dapat } \\ \text { mengembangan media website }\end{array}$ Hybrid learning berbasis kemampuan literasi digital dalam pembelajaran fisika dengan pengoptimalan layanan menu yang ada dan juga menggunakan materi lain untuk penerapannya.

\section{DAFTAR PUSTAKA}

APJII. (2017). Infografis Penetrasi \& Perilaku Pengguna Internet Indonesia . Infografis Penetrasi \& Perilaku Pengguna Internet Indonesia Survey 2017 , pp. 139.

Asyrofi, M., \& Junaedi, I. (2016). Kemampuan Representasi Matematis Ditinjau dari Multiple Intellingence Pada Pembelajaran Hybrid learning Berbasis Konstruktivisme. Unnes Journal of Mathematics Education Research , 32-39.

Griffin, P., \& Care, E. (2015). Assessment and Teaching of 21st Century Skills Methods and Approach. London: Springer.

Husamah. (2014). Pembelajaran Bauran (Blended Learning). Malang: Prestasi Pustaka.

Lawshe, C. (1975). A Quantitative Approach to Content Validity. (pp. 563-575). Personal Psycology.

Lee, W. W., \& Owens, D. L. (2004). Multimedia-Based Instructional Design. San Francisco: Pfeiffer.

Rahayu, T., \& Mayasari, T. (2018). Profil Kemampuan Awal Literasi Digital dalam Pembelajaran Fisika Siswa SMK Kota Madiun. Seminar Nasional Quantum (pp. 1-7). Yogyakarta: Pend.Fisika UAD.

Techataweewan, W., \& Prasertsin, U. (2017). Development of digital literacy indicators for Thai undergraduate students using mixed method research. Social Sciences , 1-7. 